\title{
A preliminary pharmacognostical study on leaves and flowers of Michelia champaca L. M agnoliaceae
}

\section{K. N.G eetha*, K .J eyaprakash and Y. P. Nagaraja}

Department of Biotechnology, Nagarjuna College of Engineering and Technology, Mudugurki Village, Venkatagirikote -Post, Devanahalli Taluk, Bangalore-562110 (Karnataka), INDIA

*Corresponding author. E-mail: geethakn2@yahoo.com

\begin{abstract}
The present investigation was conducted to establish pharmacognostical profile for the leaves and flowers of Michelia champaca L. (Magnoliaceae) in order to establish its complete profile to aid in its identification and avoid confusion in taxonomic level for different species of the same genus. The study included macroscopical, organoleptical, microscopical and preliminary phytochemical analysis of the leaves and flowers. The study of the organoleptical evaluation revealed the presence of colour, odour and texture. The microscopic analysis showed the differences in cell structures, arrangement and shape of leaves and flowers. The physical characters of various solvent extracts showed the presence of colour, odour and consistency of the powdered leaves and flowers. Finally, the preliminary phytochemical analysis confirmed for the presence of alkaloids, saponins, tannins, glycosides, carbohydrates, amino acid, flavonoids and sterols in both leaves and flowers. The present findings may be used to establish the authenticity of leaves and flowers of Michelia champaca L. for their proper identification and standardization in order to collect raw plants for the preparation of herbal drugs.
\end{abstract}

Keywords: Michelia champaca L., Leaves, Flowers, Pharmacognocy

\section{INTRODUCTION}

The use of herbal medicine for the treatment of diseases and infections is a safe and traditional therapy. Hence, medicinal plants have been receiving great attention worldwide because of their safe utility (Najafi and Deokule, 2010). M ichelia champaca L. belongs to family Magnoliaceae is commonly called as Champak or Golden Champa. It is wild in the forests of the eastern sub Himalayan tract and lower hills up to 3000ft MSL and also in Assam, Myanmar, South India and Western Ghats (Chopra et al., 1956). Leaves are simple, alternate, petiole 1 to $3 \mathrm{~cm}$ long, elliptic, lanceolate, spiral, and reticulate. Flowers are solitary, yellow, dull-yellow when fresh, orange when old and fragrant (Gamble, 1921). In India this plant is cultivated in gardens and near the temples for its fragrant flowers and handsome foliage. Its volatile oil is highly esteemed in perfumery and in useful in cephalalgia, ophalagia, ophthalmia, gout and rheumatism. Its fruits and flowers are attributed to several useful properties (Chopra et al ., 1956; The Wealth of India, 1962). Rangasamy et al. (2007) investigated the antimicrobial activity of dichloromethane (DCM) extract of the powdered leaves against Cladosporium cucumerinum and Menifest activity against Colletrotrichum glocosporium. Balurgi et al. (1997) showed that the leaves contain parthenolide. It is showed cytotoxic activity towards the human epidermoid carcinoma of the nasopharynx test system (Hoffmann et al.,1977). Further, the anti-inflammatory and antipyretic activities of methanolic extract of flowers (Vimala et al., 1997) and the isolation of flavonoids and other non - nitrogenous constituents from the flowers (Shalini and Jaggi, 2009) have also been investigated. The flower aqueous extracts of M .champaca L. possess significant antiulcer activity than the other (leaf alcoholic, flower alcoholic, leaf aqueous) three extracts (Surendra Kumar et al., 2011). The present study was under taken to know the pharmacognostical characteristics of leaves and flowers of M. chempaca L. and to determine the anatomical, physical characters for the quality control of the herbal drugs.

\section{MATERIALS AND METHODS}

Specimen collection: The plant specimens for the proposed work were collected in the month of November and December, 2009 from Thottabetta, Nilgiris of Tamil $\mathrm{Nadu}$, in India. The specimens were identified by using "The Flora of the presidency of Madras", vol-1, (Gamble, 1921) and "The Flora of the Tamilnadu carnatic"-part1(Mathew, 1983) and later authenticated by Dr. K Ravi Kumar, Assistant Director, FRLHT, Bangalore. A voucher specimen (NCET-BT-047) was deposited in the Department of Biotechnology, Nagarjuna college of Engineering and Technology, Bangalore. Healthy leaves and flowers of the plants were selected, removed and 
fixed in formalin: acetic acid: $70 \%$ ethanol in the ratio of 0.5: 0.5: 9 mixtures.

M acroscopic and microscopic analysis: For the macroscopy, leaf surface, lamina shape, margin, apex, venation and flower colour occurrence and hairs were studied and for the microscopical studies, uniform, thin sections were cut from the leaves and flowers using microtome. Then the sections were stained with safranin ( $0.5 \%$ safranin solution prepared in $50 \%$ alcohol) followed by Haematoxylin stain and dehydrated. The treated samples were finally mounted in Canada balsam. The structures of trichomes, cuticle, epidermis, collenchymatous cells, vascular bundles, paranchymatous cells, resin cells, lignins and starch grains were observed and studied by using Leitz Nikon binocular microscopy according to the method of Khandelwal (1999).

Phytochemical analysis: The powdered leaves and flowers of the M.champaca L. were subjected for the analysis of physical character parameters like- colour, odour and consistency of various soluble extracts by the procedure prescribed by Indian pharmacopoeia (1985). The mature, healthy leaves and flowers of the plant were dried in shade so as to prevent the decomposition of chemical constituents. The sample was powdered in electronic blender and phytochemical studies were done according to the method of Kokate (2000).

\section{RESULTS AND DISCUSSION}

M acroscopical and organoleptical characters: In the present investigation, the leaves of M champaca $\mathrm{L}$ were found to be smooth surfaced, lamina ovate, margin entire, apex acute, base symmetrical, simple venation and orange flowers with very few hairs. The observation is concurrent with the taxonomical flora of Gamble (1921). Powdered leaf was subjected to organoleptical characters. It had dark green, odourless, slightly bitter taste, gritty texture and uneven coarse particles. The powdered flower is orange brown, characteristic odour, mucilaginous and bland taste, gritty texture and uneven coarse particles. M icroscopic characters

Leaf: The leaf consists of single layered epidermis, covered with a thin cuticle and the uniseriate covering trichomes are abundantly found on both sides. Yu-fei and Jun-Rong (1993) investigated three (Tsoongiodendron Chun., Manglietiastrum Law., and Parakmeria Hu et Cheng.) Chinese endemic genera in Magnoliaceae that the cells of upper epidermis had irregular forms with curved walls and the characters of lower epidermal cells were similar to those of upper ones but possessed lots of stomatal apparatus scattered among them. The midrib of leaf showed dorsiventral structure and distinct plano convex outline in the basal and middle region (Fig.1). In the present study, it was observed that the clusters of collenchymatous cells covering the vascular bundles were found over the midrib portion of the leaf. The central portion of midrib is occupied by vascular bundles which are having heart shaped outline. In the vascular bundles, the xylems are highly lignified and the phloems are non- lignified. The stained (dark brown to brownish orange) leaf sections showed the presence of resin cells within it. Further the transverse section clearly exhibited for the occurrence of poly phenol groups along the vascular bundle regions when stained with neutral ferric chloride solution. The presences of lignins were seen throughout the section in both the midrib and laminar regions, when stained with phlorogulucinal and hydrochloric acid. The lamina

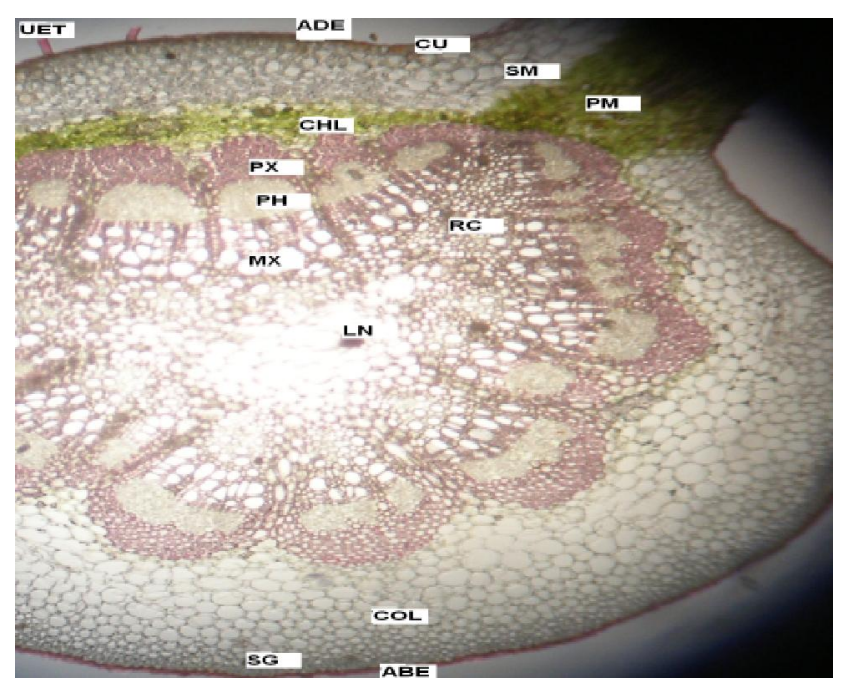

Fig. 1. T.S of leaf of M . champaca L. through the midrib and lamina (ABE: Abaxial epidermis, ADE: Adaxial epidermis, CHL: Chlorenchyma, COL: Collenchyma, CU: Cuticle, LN: Lignin, M X: M eta xylem, PH: Phloem, PM : Palisade mesophyll, PX: Protoxylem, RC: Resin cell, SG : Starch grain, SM : Spongy mesophyll, U ET: U niseriate epidermal trichome).

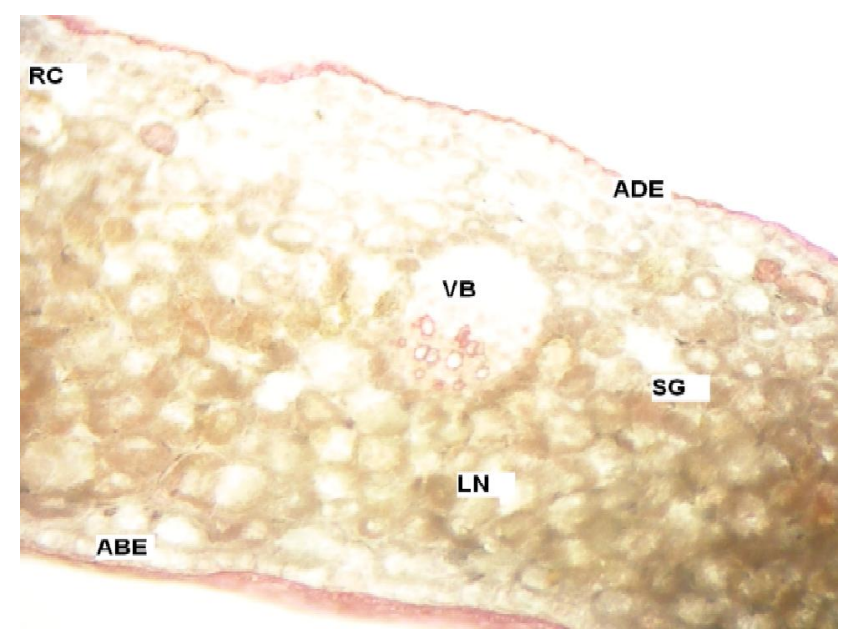

Fig. 2. T.S of flower of $M$. champaca $L$ through the midrib. (ABE: Abaxial epidermis, ADE : Adaxial epidermis, LN: Lignin, RC: Resin cell, SG : Starch grain). 
Table 1. Percentage of dry weight and physical characters of the leaves and flowers of M.champaca L.

\begin{tabular}{|c|c|c|c|c|}
\hline L eaves extract & $\begin{array}{l}\text { Percentage of } \\
\text { dry weight }\end{array}$ & Colour & Odour & Consistency \\
\hline Acetone & 03.23 & Dark green & Characteristic & Sticky \\
\hline Ethanol & 14.16 & Dark green & Characteristic & Sticky \\
\hline Benzene & 00.23 & Dark green & Not characteristic & Waxy \\
\hline Chloroform & 00.9 & Fluorescent green & Not characteristic & Waxy \\
\hline Petroleum ether & 07.00 & Dark green & Characteristic & Waxy \\
\hline \multicolumn{5}{|l|}{ F lower s extract } \\
\hline Acetone & 0.32 & Fluorescent yellow & Characteristic & Sticky \\
\hline Ethanol & 03.10 & Yellowish brown & Characteristic & Sticky \\
\hline Benzene & 04.05 & Reddish brown & Non characteristic & Waxy \\
\hline Chloroform & 00.53 & Yellowish brown & Non characteristic & Waxy \\
\hline Petroleum ether & 15.41 & Reddish brown & Characteristic & Viscous liquid \\
\hline
\end{tabular}

Table 2. Preliminary phytochemical analysis of leaves and flowers of M .champaca L.

\begin{tabular}{|c|c|c|c|c|c|c|}
\hline \multirow[b]{2}{*}{$\begin{array}{l}\text { Phytochemical } \\
\text { constituents }\end{array}$} & \multicolumn{6}{|c|}{ L eaf extraction } \\
\hline & A cetone & Ethanol & Aqueous & Benzene & Chlor oform & $\begin{array}{l}\text { Petroleum } \\
\text { ether }\end{array}$ \\
\hline Alkaloids & + & + & - & - & + & - \\
\hline Saponins & - & - & - & - & - & - \\
\hline Tannins & - & - & + & - & - & - \\
\hline Glycosides & + & + & - & - & + & - \\
\hline Carbohydrates & - & + & - & - & - & - \\
\hline Amino acid & + & + & + & - & + & - \\
\hline Flavonoids & - & + & + & - & - & - \\
\hline \multirow[t]{2}{*}{ Sterols } & - & - & - & + & + & + \\
\hline & \multicolumn{6}{|c|}{ Flower extraction } \\
\hline Alkaloids & - & + & - & + & + & + \\
\hline Saponins & - & - & - & - & - & - \\
\hline Tannins & + & + & + & - & - & - \\
\hline Glycosides & + & + & - & - & + & - \\
\hline Carbohydrates & + & + & - & - & - & - \\
\hline Amino acid & + & + & + & - & + & - \\
\hline Flavonoids & + & + & + & - & - & - \\
\hline Sterols & + & + & - & + & + & + \\
\hline
\end{tabular}

showed single layered epidermis on cells of both adaxial and abaxial side. The presence of 5-7 layers of palisade mesophyll cells in abaxial side was followed by 4-6 layers of spongy mesophyll cells in adaxial side and they were oval in shape.

Flower : The consists of single layered epidermis on both the sides flower (Fig. 2). A cluster of paranchymatous and collenchymatous cells were seen in the section, the xylems were slightly lignified. The stained section showed the presence of resin cells throughout the section. The occurrences of lignins on both midrib and laminar regions (pink colour) and abundant starch grains were also seen throughout the section.

Phytochemical screening : The percentage of dry weight of leaf extracts were observed by using different solvent systems. The maximum weight was observed in alcohol extract (14.16) followed by petroleum ether (7.00), acetone (3.23), benzene (0.23) and chloroform (0.09). Further, the leaves treated with acetone and alcohol showed dark green in colour, sticky in consistency and characteristic odour. The benzene and chloroform treated leaves showed waxy consistency, non characteristic odour, but fluorescent green colour in chloroform and dark green colour in benzene solvents (Table 1). While in case of 
flowers, the dry weight was maximum in petroleum ether (15.41) followed by benzene (04.05), alcohol (3.10), chloroform (0.53) and acetone (0.32). The flowers of $M$. champaca when treated with acetone and alcohol extracts showed sticky in consistency, characteristic odour but fluorescent yellow colour in acetone extract and yellowish brown colour in alcohol extract. The benzene and chloroform extract showed waxy consistency, non characteristic odour but reddish brown in benzene and yellowish brown in chloroform extract. The petroleum ether extract showed viscous liquid consistency, reddish brown in colour and characteristic odour (Table 1). The phytochemical analysis of the leaves and flowers of plant showed the presence of alkaloids, tannins, glycosides, carbohydrates, amino acids, flavonoids and sterols in different solvent systems (Table 2). The leaf extraction of acetone contained alkaloids, glycosides and amino acids, the ethanol contained alkaloids, glycosides, carbohydrates, amino acids and flavonoids, the aqueous extract contained tannins amino acids and flavonoids, the benzene and petroleum ether contained only sterols and the chloroform extract contained alkaloids, glycosides, amino acids and sterols. The flower extraction of acetone contained tannins, glycosides, carbohydrates, amino acids, flavonoids, and sterols, the ethanol extraction contained alkaloids, tannins, glycosides, carbohydrates, amino acids, flavonoids, and sterols, the aqueous extraction contained only tannins, amino acids and flavonoids, the benzene and petroleum ether extraction only alkaloids and sterols and the chloroform extraction contained alkaloids, glycosides, amino acids and sterols. Jarald et al. (2008) investigated in flower buds extraction of petroleum ether contained fats and alkaloids, acetone extraction contained only tannins, the chloroform extract contained sterols and alkaloids, ethanol extract contained carbohydrates, flavonoids, alkaloids and tannins and the aqueous extract contained carbohydrates, flavonoids, alkaloids and saponins. The petroleum ether extract of the dried flowers contained nalkane hydrocarbons, unsaturated aliphatic ketones, beta sitosterols and quercetin. The quercetin forms the first report of its occurrence in the genus Michelia (Shalini and Jaggi , 2004). Lago et al. (2009) reported that volatile oils contained six sesquiterpene hydrocarbons, four oxygenated sesquiterpene, and two aliphatic alcohols from water using dichloromethane solvent in leaves of M . champaca L.

There appears to be no Pharmacognostical work of this valued (leaves and flowers) traditional medicinal plant. In the present study, Pharmacognostical evaluations of leaves and flowers of Michelia champaca L. provided useful information with regard to its proper identity and may help to differentiate from the closely related species of Michelia. The parameters observed and reported may used in selecting the correct herbal specimen for the preparation of the herbal drug.

\section{REFERENCES}

Balurgi, V.C., Rojatkar,S.R., Pujar,P.P., Patwardhan,B.K. and Nagrasampagi, B.A. (1997). Isolation of parthinolide from the leaves of Michelia champaca L. J ournal of Indian drugs, 34: 415 .

Chopra, R.N., Nayar, S.L., and Chopra, I.C., (1956). Glossary of Indian medicinal plants: National institute of science communication (NISCOM) CSIR, New Delhi. pp 166.

Gamble, J.S. (1921) Flora of the presidency of madras, Vol-1, Adlard \& son Ltd, 21, Hart street, W.O, London. pp 8-9.

Hoffman, J.J., Torrance, S.J., Wiedhopf, R.M and Cole J.R. (1977). Cytotoxic agents from Michelia champaca and Talauma avata : partheno- lide and costunolide. J Pharm Sci., 66:883-884.

Indian pharmacopoeia (1985). Vol-2, 3ed: Govt. of India. Ministry of Health. Controller of publications, New Delhi. pp. 36-74.

Khandelwal, K.R. (1999). $6^{\text {th }}$ Edn, Practical PharmacognocyTechniques and Experiments: Nirali prakashan publishers.pp 15-37.

Kokate, C.K. (2000). Practical pharmacognocy: Nirali prakashan publishers. Delhi-Reprint. pp16-29.

Lago, J.H.G., Favero, O.A and Romoff, P. (2009). Chemical composition and seasonal variation of the volatile oils from leaves of M . champaca L. Magnoliaceae, Brazilian J ournal of Pharmacognocy, 19 (4): 880-882.

Mathew, K.M. (1983). The flora of the Tamilnadu carnatic, Part -1: The Rapinat Herbarium, St. Joseph's college, Tiruchirapalli. India.

Najafi, S. and Deokule. S.S. (2010). Pharmacognostical study of Tylophora dalzelli Hook.f. J ournal of M edicinal Plants Research., 4(5): 403-406.

Rangasamy, O., Raoelison,G., Rakotoniriana, E., Cheuk, K., Ratsimamanga, U., Quetin-Leclercq, J., Gurib-Fakim, A. and Subratty, H. (2007). Screening for anti-infective properties of several medicinal plants of the Mauritians flora. J ournal of Ethno pharmacology, 109: 331-337.

Shalini Kapoor and Jaggi, R.K. (2004). Chemical studies on flowers of Michelia champaca L. Indian Journal of Pharmaceutical Science., 66: 403-406.

The Wealth of India. (1962) Vol-6. Council of scientific \& Industrial Research: New Delhi. pp 370.

Vimala, R., Nagarajan S., Alam, M., Susan, T. and Joy, S. (1997). Anti inflammatory and antipyretic activities of M .champaca L. Indian J ournal of Experimental Biology, 35 (12): 13101314.

Yu-fei, W and Jun-rong, T. (1993). Studies on the leaf cuticle of three Chinese endemic genera in Magnoliaceae, Acta Botanica Sinica., 35:106-110.

Surendra Kumar, M., Aparna, P., Poojitha,K., Karishma, S.K., and Astalakshmi,N. (2011). A comparative study of Michelia champaca L. flower and leaves for anti - ulcer activity International J ournal of Phar maceuticals Sciences and Research, 2(6): 1554-1558. 